\title{
Posthumous inequalities and stratification Of human remains in Spain
}

\author{
Alexandra Staniewska \\ Adam Mickiewicz University
}

\begin{abstract}
In many countries dealing with past, mainly internal, violence exhumations of the victims are seen as a way of social closure. It is a case in Spain, where the importance of human rights is stressed and extended to post-mortem conditions and proper reburials deemed necessary. In recent years, many associations and organisations have been set up to exhume mass graves, and exhumations tend to attract media attention. The search for the human remains and reburial of civil war victims has even penetrated political parties' programmes. However, during my ethnographic research in Spain, I have encountered that principles of universality of human rights and dead's dignity are not applied to all remains. I want to present different inequalities between human remains and discuss how Spanish society stratifies their dead. Given such context, the necessity of exhumations and reburials will be subjected to critique, with the aim to specify their individual and social motivations.
\end{abstract}

Keywords: cemeteries, exhumations, inhumations, mass graves, reburials 